\title{
Archipel
}

ARCHIPEL Études interdisciplinaires sur le monde insulindien

$91 \mid 2016$

Varia

\section{The French-Indonesian archaeological project in Kota Cina (North Sumatra): the 2014-2015 excavations}

Le programme archéologique franco-indonésien de Kota Cina (Sumatra-Nord):

fouilles 2014-2015

Daniel Perret, Heddy Surachman, Repelita Wahyu Oetomo, Churmatin Nasoichah, Deni Sutrisna and Mudjiono

\section{(2) OpenEdition}

Electronic version

URL: http://journals.openedition.org/archipel/298

DOI: 10.4000/archipel.298

ISSN: 2104-3655

Publisher

Association Archipel

Printed version

Date of publication: 15 May 2016

Number of pages: 3-26

ISBN: 978-2-910513-74-0

ISSN: 0044-8613

\section{Electronic reference}

Daniel Perret, Heddy Surachman, Repelita Wahyu Oetomo, Churmatin Nasoichah, Deni Sutrisna and Mudjiono, «The French-Indonesian archaeological project in Kota Cina (North Sumatra): the 2014-2015 excavations », Archipel [Online], 91 | 2016, Online since 01 May 2017, connection on 24 April 2019. URL : http://journals.openedition.org/archipel/298; DOI : 10.4000/archipel.298 


\title{
Archéologie et épigraphie de Sumatra
}

\author{
DANIEL PERRET ${ }^{1}$, HEDDY SURACHMAN ${ }^{2}$, \\ REPELITA WAHYU OETOMO ${ }^{3}$, \\ CHURMATIN NASOICHAH ${ }^{4}$, DENI SUTRISNA ${ }^{5}$, MUdJIONO $^{6}$
}

The French-Indonesian archaeological project
in Kota Cina (North Sumatra): the 2014-2015 excavations

For the last twenty years, the French-Indonesian archaeological cooperation has been particularly dynamic in the North Sumatra Province, activity related to intensive excavations and multidisciplinary studies conducted on several old settlement sites: on the west coast, Barus-Lobu Tua (1995-2000, $1000 \mathrm{~m}^{2}$ excavated, dating from the ninth century until the end of the eleventh century $\mathrm{CE}$ ), and Barus-Bukit Hasang (2001-2005, $470 \mathrm{~m}^{2}$ excavated, dating from the twelfth century until the beginning of the sixteenth century CE); in the centre of the island (Padang Lawas region), Si Pamutung (2006-2010, $1092 \mathrm{~m}^{2}$ excavated, dating from the ninth century until the thirteenth century CE).

Since 2011, another old settlement site has been studied in the framework of this co-operation ${ }^{7}$. This site is Kota Cina, located at $03^{\circ} 43^{\prime} \mathrm{N}$ and $98^{\circ} 39^{\prime} \mathrm{E}$, in the kelurahan of Paya Pasir, kecamatan of Medan Marelan, today part of the northern suburbs of Medan, a city of over two million inhabitants, capital

1. École française d'Extrême-Orient, Jakarta.

2. Pusat Penelitian Arkeologi Nasional Indonesia, Jakarta.

3. Pusat Penelitian Arkeologi Nasional Indonesia, Balai Arkeologi Medan.

4. Pusat Penelitian Arkeologi Nasional Indonesia, Balai Arkeologi Medan.

5. Pusat Penelitian Arkeologi Nasional Indonesia, Balai Arkeologi Medan.

6. Pusat Penelitian Arkeologi Nasional Indonesia (retired).

7. This project, financially supported by the École française d'Extrême-Orient since 2011, is also funded by the Commission consultative des recherches archéologiques à l'étranger (Advisory Commission for Archaeological Research Abroad) under the French Ministry of Foreign Affairs, since 2014. 
of the North Sumatra province. Kota Cina is also less than ten kilometres away from the harbour of Belawan on the Strait of Malacca. (fig. 1)

A review of the state of knowledge and hypotheses regarding the history of Kota Cina before the resumption of research in 2011, as well as several preliminary results obtained between 2011 and 2013, have been put forward in a previous contribution to this journal. ${ }^{8}$

The aims of the present article are to introduce the preliminary results of the 2014 and 2015 excavations, to refine comparisons between excavated areas at the site as well as comparisons with other more or less contemporary sites in North Sumatra as regards density of several types of finds, and finally to discuss research prospects based on the progress of the project.

\section{General data on the ongoing project}

Overall, fourteen excavations were conducted between 2011 and 2013, representing an area of approximately $190 \mathrm{~m}^{2}$ with some $123 \mathrm{~m}^{3}$ of excavated soil. Thirty seven excavations were conducted in 2014 and 2015, resulting in a total excavated area of $384 \mathrm{~m}^{2}$ since 2011 with some $343 \mathrm{~m}^{3}$ of excavated soil (fig. 2). Five areas have been explored during these two stages. From the north to the south: area $\mathrm{H}$ (excavations $\mathrm{KC} 39, \mathrm{KC} 40, \mathrm{KC} 44: 33 \mathrm{~m}^{2}, 48.3 \mathrm{~m}^{3}$ ), situated between the southern tip of Lake Siombak and Parit Belatjang, the drainage ditch crossing the northern part of the site, and to the east of the road leading to the office of the Paya Pasir subdistrict (fig. 3); area D (fig. 4), situated to the south of Parit Belatjang, near its confluence with the drainage ditch bordering the site to the west (KC15, KC16, KC21, KC22, KC37, KC38, $\mathrm{KC} 45, \mathrm{KC} 46, \mathrm{KC} 50: 40 \mathrm{~m}^{2}, 49.6 \mathrm{~m}^{3}$ ); area $\mathrm{E}$ (fig. 5), between area B -where a brick structure was excavated in 2013-, and area $\mathrm{C}$, rich in brick remains (KC31, KC32, KC35, KC41, KC42, KC43, KC47, KC48, KC49, KC51: $61 \mathrm{~m}^{2}, 56.5 \mathrm{~m}^{3}$ ); area $\mathrm{F}$ (fig. 6), in the south part of the site, near the village of Kota Cina public school (KC19, KC20, KC24, KC25, KC29, KC30, KC33, $\mathrm{KC} 34, \mathrm{KC} 36: 36 \mathrm{~m}^{2}, 39.8 \mathrm{~m}^{3}$ ); area $\mathrm{G}$ (fig. 7), which seems to represent the southern limit of the site $(\mathrm{KC} 17, \mathrm{KC} 18, \mathrm{KC} 23, \mathrm{KC} 26, \mathrm{KC} 27, \mathrm{KC} 28$ : $24 \mathrm{~m}^{2}, 25.2 \mathrm{~m}^{3}$ ). Thus, eight areas have been excavated since 2011. Several areas excavated at the beginning of the project are no longer available for archaeological research, due to the rapid development of the site for private housing. Furthermore, as the site is situated just above sea level with a tidal water table approximately 0.50 metre below the present surface, the use of water pumps is necessary in most of the digs.

A preliminary recapitulation of the main types of finds collected in 2014 and 2015 yields the following figures:

8. See D. Perret et al., "The French-Indonesian Archaeological Project in Kota Cina (North Sumatra): Preliminary Results and Prospects", Archipel, 86, 2013: 73-111. 


\begin{tabular}{|c|c|c|c|c|c|}
\hline & $\begin{array}{c}\text { Earthenware } \\
\text { (shards) }\end{array}$ & $\begin{array}{c}\text { Stoneware } \\
\text { and porcelain (shards) }\end{array}$ & $\begin{array}{c}\text { Glass } \\
\text { (shards) }\end{array}$ & $\begin{array}{c}\text { Faunal } \\
\text { and human remains }\end{array}$ & Coins \\
\hline Quantity & 97,815 & 32,187 & 554 & & 388 \\
\hline Weight (g) & 943,658 & 397,027 & & 89,251 & \\
\hline
\end{tabular}

A preliminary recapitulation of the main types of finds collected since the beginning of the project in 2011 yields the following figures:

\begin{tabular}{|c|c|c|c|c|c|}
\hline & $\begin{array}{c}\text { Earthenware } \\
\text { (shards) }\end{array}$ & $\begin{array}{c}\text { Stoneware } \\
\text { and porcelain } \\
\text { (shards) }\end{array}$ & $\begin{array}{c}\text { Glass } \\
\text { (shards) }\end{array}$ & $\begin{array}{c}\text { Faunal } \\
\text { and human remains }\end{array}$ & Coins \\
\hline Quantity & 133,138 & 43,885 & 683 & & 698 \\
\hline Weight (g) & $1,234,640$ & 536,778 & & 125,983 & \\
\hline
\end{tabular}

A preliminary recapitulation of the remaining finds includes 829 artifacts or fragments of artifacts of iron, 105 of bronze, 39 of other metals, some 105 kilograms of iron slags and ferruginous concretions, 315 stone or glass beads, 26 shards of glazed earthenware, 202 fragments of cut or uncut wood weighting between a few grams and several kilograms, 171 fragments of artifacts made of stone, nearly a kilogram of $i j u k^{9}$ (raw or strings), 6,600 grams of resins. To this list should be added terracotta fragments, which are not brick fragments, as well as fruits and seeds.

\section{Density of religious buildings}

The discovery of three sections of brick walls during the 2013 excavations conducted in area B raised the question of the density of structures made of permanent materials in the northern half of the site. In fact, excavations conducted in the 1970s revealed two relatively large brick structures: one near the confluence of Parit Belatjang and the western drainage ditch (estimated dim., $12.5 \mathrm{mx} 13 \mathrm{~m})$; the other, a rectangular structure $(14 \mathrm{~m} \times 6.8 \mathrm{~m})$, divided by brick cross-walls into three separate sections, to the south of the later one. Both structures would therefore be located in our area D or area $\mathrm{B}^{10}$. Furthermore, in the 1970s, a brick and stone construction was noticed near Keramat Pahlawan and the small Chinese shrine still in use today in area $\mathrm{C}$, some 40 metres to the east of the drainage ditch. It is perhaps a portion of this structure that was uncovered in 2010 by archaeologists from the Balai Arkeologi Medan. Therefore, the sector between the confluence of Parit Belatjang and the western drainage ditch on the one hand, Keramat Pahlawan

\section{Fibres of sugar palm (Arenga Pinnata).}

10. It should be noted that excavations conducted in the 1970s were not recorded on a topographical map of the site. It is thus impossible to pinpoint the exact location of these structures now. 
and the Chinese shrine on the other hand, some 260 metres to the south, seems to shelter a high number of ancient structures using permanent materials. One of the objectives of the 2014-2015 fieldworks was to get a better grasp of this density. A simple method has been employed for this, i.e. soil borings using several iron rods to detect bricks. Wherever possible, these borings have been conducted at regular intervals (usually one metre), outside buildings, ponds, roads and pieces of land not accessible for archaeological research (fig. 8).

One of the first results of this survey has been to ascertain the basic plan of the brick structure excavated in area B in 2013 (see Perret et al. 2013). Made of three sections, it would have measured some 13 metres 66 metres. According to these dimensions, it is not impossible that this construction is the same as the three-section building reported in the $1970 \mathrm{~s}^{11}$. Another interesting result was the delimitation of a 30 metres $\times 30$ metres sector, very rich in bricks down to a depth of one metre, in the vicinity of Keramat Pahlawan and the small Chinese shrine. This is very probably a complex consisting of several structures enclosed within a brick wall, possibly the main religious complex of the site.

Most of area $\mathrm{D}$ has been similarly surveyed in 2015, ending with a negative result, as it did not reveal any trace of old brick concentration. However, thanks to information provided by a witness of the archaeological researches conducted in the 1970s, it has been possible to situate one of the brick remains excavated at that time. Today it is located right under a house (close to KC22), and thus impossible to dig anew. It is perhaps the three-section building remains reported at the time.

Surveys and excavations conducted since 2014 allow us to confirm that in former times the sector between the drainage ditch crossing the northern part of the site and the vicinity of the modern Chinese shrine, was not completely covered with structures using permanent materials, but sheltered various separate buildings.

Still in relation with buildings made of permanent materials, surveys and excavations have been conducted in 2014 and 2015 in area G, located in the south part of the site. Two stone images of Amitābha in a style dating to the end of the Cōla period (beginning of the twelfth century AD), were uncovered by chance by villagers during or soon after the Japanese occupation and in 1973. The excavation conducted at KC18 uncovered two clearly distinct levels of disturbed brick fragments, the deepest $(85-110 \mathrm{~cm})$ perhaps related to an occupation floor. Excavations KC23 and KC26 nearby, as well as a systematic survey conducted in 2014, did not yield conclusive evidence of the presence there of structures using permanent materials. Following information provided by villagers, a more detailed survey was carried out in the same sector in 2015 .

11. However, the fact that the recent excavation in area B yielded a large number of artifacts lead us to think that this structure is different from the one uncovered in the 1970s. 
A negative result came out, except close to a recently built house. Very probably, as in area D, most of what was left of the old structure has been destroyed during the recent construction or is still buried under this house, and is therefore out of reach for excavation in the decades to come.

\section{Shell midden layers}

At Kota Cina, two main types of features reveal traces of old settlement. There are shell midden layers, of various thickness, which represent accumulations of household waste, and wooden posts, traceable through remains of fragments or postholes (fig. 9). Here, we focus on the rate of occurrence of midden layers and concentrations uncovered since 2011.

None of the six excavations conducted in area $G$, near the south boundary of the archaeological site, as it is presently hypothesized, yielded midden layers or concentrations. Towards the north, of the nine excavations carried out in area $\mathrm{F}$, two revealed midden layers (with a maximum thickness of $20 \mathrm{~cm}$ in $\mathrm{KC} 33$ - cf. fig. 10 -, and $10 \mathrm{~cm}$ in $\mathrm{KC} 34$ ), and three yielded midden concentrations (KC19, KC25, KC29). Of the six excavations carried out in area $\mathrm{C}$, one revealed a midden layer $(\mathrm{KC} 11)$ and one $(\mathrm{KC} 6)$ midden concentration. In area $\mathrm{E}$, seven of the ten excavations yielded midden concentrations (KC31, KC32, $\mathrm{KC} 35, \mathrm{KC} 41, \mathrm{KC} 42, \mathrm{KC} 49, \mathrm{KC} 51)$. None of the five excavations conducted in area $\mathrm{B}$ yielded a midden layer or concentration. Six of the nine excavations carried out in area $\mathrm{D}$ revealed midden layers (with a maximum thickness of $20 \mathrm{~cm}$ in $\mathrm{KC} 21, \mathrm{KC} 22$ and $\mathrm{KC} 46 ; 50 \mathrm{~cm}$ in $\mathrm{KC} 37 ; 30 \mathrm{~cm}$ in $\mathrm{KC} 45 ; 60 \mathrm{~cm}$ in $\mathrm{KC50}$ ). Of the three excavations carried out in area $\mathrm{A}$, only $\mathrm{KC} 7$ yielded midden layers. Among the three excavations conducted in area H, KC40 revealed a midden layer with a maximum thickness of $10 \mathrm{~cm}$. In this area, it is chiefly excavation KC44 $\left(25 \mathrm{~m}^{2}\right)$ which attracts attention, as its stratigraphy reveals three successive midden layers. The nearest to the present soil surface, with a maximum thickness of some $10 \mathrm{~cm}$, covers almost the whole surface area of excavation at a depth between 50 and $60 \mathrm{~cm}$. The middle layer, also with a maximum thickness of some $10 \mathrm{~cm}$, appears clearly in the east and south stratigraphies, and covers approximately a third of the surface area of excavation. The deepest midden layer, approximately $5 \mathrm{~cm}$ thick, appears at a depth of some $110 \mathrm{~cm}$, clearly visible in the stratigraphies of the southeast corner. However, its size could not be ascertained due the constant flooding at the bottom of the excavation. As shellfish species in this deep layer look different from the species in the upper layer, their identification may reveal important indications regarding the environmental history of the site. In fact, $\mathrm{KC} 44$ is the first excavation of this project to have revealed a stratigraphy showing three very distinct midden layers. The only other occurrence of multiple midden layers was uncovered in KC7 (area A) ${ }^{12}$.

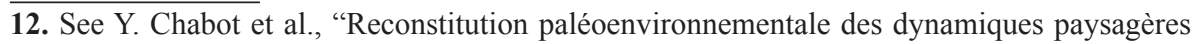


These multiple layers indicate a dense but irregular occupation. KC7 and $\mathrm{KC} 44$ are located in the vicinity of the supposed northern boundary of the site, to the north of Parit Belatjang, the drainage ditch crossing the northern part of the site. Further excavations will be needed in order to check if this dense but irregular occupation is a common feature in this northern part of the site. A priori, the frequency and unmatched thickness of midden layers in area D indicate a dense and regular occupation. As these layers also yielded large quantities of finds, area $\mathrm{D}$ positions itself as one of the main, if not the main, site centres of occupation. It is certainly no coincidence that this area, as well as the neighbouring area $\mathrm{B}$, have already yielded several structures made of durable materials. In the southern part of the site, based on the frequency in midden layers, $\mathrm{F}$ seems also to have been an important focus of occupation. By contrast, the absence of shells in area $\mathrm{G}$ would be an indication of a marginal occupation zone, probably located near the southern boundary of the site.

\section{Wood remains at Kota Cina}

The presence of wood remains figures among the features making of Kota Cina an exceptional archaeological site in the northern half of Sumatra whose humid environment (cf. fig. 11) allows for the preservation of organic remains such as wood. Based on a provisional tally, 200 wood fragments - most of them the remains of posts - were collected between 2011 and 2015. However, the year 2012 saw the discovery (in KC7) of a boat framing member which, by means of AMS radiocarbon dating, yielded a dating in the bracket mid $12^{\text {th }}$ to mid $13^{\text {th }}$ century $\mathrm{AD}^{13}$, while another boat framing member was uncovered in 2015, in area H, precisely in KC44 (cf. fig. 12). This find has yet to be dated.

This same area $\mathrm{H}$ also revealed remains of a wood structure. It was uncovered in excavation $\mathrm{KC} 40$, the stratigraphy of which revealed five layers, from silty at the top to sandy at the bottom. A midden layer, some $10 \mathrm{~cm}$ thick, covers virtually the whole square, at a depth between 55 and $70 \mathrm{~cm}$. Approximately $50 \mathrm{~cm}$ below this layer, at a depth of about $120 \mathrm{~cm}$, the excavation uncovered the upper part of a wood structure made of squared-off poles and pruned branches, as well as planks (cf. fig. 13), some of these elements still bearing $i j u k$ cords, others still fitting together (cf. fig. 14). The constant flooding at the bottom of the excavation, combined with the collapsing of two sides of the square, prevented excavation below a depth of $140 \mathrm{~cm}$.

One of the aims of the opening of a relatively large excavation, i.e. KC44 $(5 \mathrm{~m} \times 5 \mathrm{~m})$, very close to $\mathrm{KC} 40$, was to uncover a possible extension of this structure to the south. Albeit remains of poles and wood elements horizontally arranged with cords made of $i j u k$ (cf. fig. 15) were uncovered in this square,

durant le dernier millénaire aux abords du site archéologique de Kota Cina (Sumatra-Nord, Indonésie): résultats préliminaires", Archipel, 86, 2013: 122.

13. Perret et al. 2013: 94, 95, 96. 
the low density in wood remains does not allow us to interpret these finds as an extension of the structure found in $\mathrm{KC} 40$. This unfortunately very damaged structure, the first of this kind uncovered so far during this project, was probably part of a pontoon or a path constructed above water or a wetland zone.

\section{Intra-site comparisons}

After five stages of excavations, which yielded a large quantity of finds, it is possible to make some preliminary comments regarding the distribution per area and per excavated cubic metre of three types of finds commonly found on the site: earthenware, stoneware and porcelain, faunal remains ${ }^{14}$. Earthenware, stoneware and porcelain are represented by some 175,000 shards weighting more than 1,700 kilograms. The total weight of faunal remains exceeds 120 kilograms (cf. Table 7).

Density related to the quantity of earthenware shards per area ranges from 93 to 869 (cf. Table 1 and Chart 1), that is approximately a ten times difference, while the mean density is 386. Areas C, D, E exceed this mean density, E showing the highest one. Density related to the weight $(\mathrm{g})$ of earthenware shards per area ranges from 860 to 8599 (cf. Table 1 and Chart 2), that is exactly a ten times difference, while the mean density is 3546. Areas D and E exceed this mean density, E showing the highest one.

Density related to the quantity of stoneware and porcelain shards ranges from 29 to 267 (cf. Table 1 and Chart 1), that is a difference exceeding nine times, while the mean density is 125 . Areas C, D, E exceed this mean density, E showing the highest one. Density related to the weight ( $\mathrm{g}$ ) of stoneware and porcelain shards per area ranges from 355 to 3020 (cf. Table 1 and Chart 2), that is a difference exceeding eight times, while the mean density is 1466. Areas D and E exceed this mean density, E showing the highest one.

The relative representativity per cubic metre of these two types of finds is a criterion that might relate to a variety of lifestyles (cf. Tables 2 and 3 ). As regards stoneware and porcelain, this representativity ranges from $19 \%$ to $37 \%$ for the quantity, and from $26 \%$ to $46 \%$ for the weight: roughly a twofold difference between maximum and minimum. As regards quantity, this proportion is remarkably stable in five areas (A, C, D, E, F), as it ranges from $22 \%$ to $26 \%$. The three remaining areas may thus be considered as atypical, namely areas $\mathrm{H}$, $\mathrm{B}$, where the proportion of stoneware and porcelain equals or exceeds a third, and conversely $\mathrm{G}$, where it is as low as $19 \%$. The atypical nature of areas B and $\mathrm{H}$ appears also for weight, as the density in stoneware and porcelain represents almost half of the total weight of shards. An in-depth analysis of the finds, whether stoneware and porcelain or earthenware, will give us the opportunity to check if these atypical characteristics are related to a specific period of occupation, to the presence of a specific community, or to a specific activity.

14. Surface finds collected during surveys are not included in these comparisons. 
Either in terms of quantity or weight, the maximum discrepancy in density of stoneware and porcelain, as well in earthenware, does not exceed ten times. The variability between areas is much higher for the faunal remains, as it exceeds 30 times. Indeed the density in weight $(\mathrm{g})$ of faunal remains per cubic metre ranges from 17 to 528 (cf. Table 1), the mean density being 358. Areas $\mathrm{A}, \mathrm{D}, \mathrm{E}$ and $\mathrm{H}$ exceed this mean density, E showing the highest one.

Interestingly, $\mathrm{A}$ and $\mathrm{H}$, which are located north of Parit Belatjang, do not feature among the areas exceeding mean densities in earthenware, stoneware and porcelain. Here, the identification of the faunal remains might help to explain this high density.

So far D and E are the only excavated areas to show densities above the mean density for each of the three types of finds considered in this study. Curiously, none of the ten excavations conducted in area $\mathrm{E}$ revealed midden layers, but only concentrations in seven of them. Area D shows a better correlation between density in artifacts, faunal remains and midden layers, as six of the nine excavations revealed midden layers. Therefore, with the current level of knowledge regarding the site, area $\mathrm{D}$ appears the best candidate as the main ancient occupation centre of Kota Cina.

\section{Inter-sites comparisons}

The preliminary results of these five stages of excavation at Kota Cina already offer the opportunity to compare densities of earthenware, stoneware and porcelain, as well as faunal remains, collected in three old settlements in North Sumatra, dating to between the ninth century and the beginning of the sixteenth century CE: Si Pamutung (mid- $9^{\text {th }}$ c. - end of $13^{\text {th }}$ c. CE), BarusBukit Hasang (12 $2^{\text {th }}$ c. - beg. of 16th c. CE), and Kota Cina (so far dating to the end of $11^{\text {th }} \mathrm{c}$. - beg. of $14^{\text {th }} \mathrm{c}$. CE). For each type of find, if they are available, we consider densities in quantity and weight, per square and cubic metre, the density per cubic metre being obviously the most significant. As the Kota Cina project is not completed yet, comparisons provided here remain indicative as regards this site and need to be considered as trends.

For earthenware (cf. Table 4), excavations conducted in the 1970s and during the last five years at Kota Cina show the highest densities in weight, whether per square or cubic metre, with figures between $3500 \mathrm{~g}$ and $4000 \mathrm{~g}$ per cubic metre. They are higher than the density per cubic metre observed at Bukit Hasang, respectively $40 \%$ and $25 \%$ higher, and about three times higher than at Si Pamutung. If the factor "duration of the settlement" is taken into account to obtain a density per cubic metre per century of occupation, Kota Cina (2.5 centuries) is temporarily predominant with some $1400 \mathrm{~g}^{15}$,

15. This figure is obtained by the combination of results yielded by the excavations conducted recently with the excavations conducted in the 1970 s. 
while Bukit Hasang (4.5 centuries) records about $600 \mathrm{~g}$, and Si Pamutung (4.5 centuries) reveals a figure lower than $300 \mathrm{~g}$.

As regards stoneware and porcelain (cf. Table 5), with 125 shards per cubic metre $^{16}$, Kota Cina ranks first, followed by Bukit Hasang and Si Pamutung. If the duration of the settlement is taken into account, Kota Cina shows the highest density per century (50), followed by Bukit Hasang (23), and lastly by Si Pamutung (9).

In quantity, the proportion per cubic metre of stoneware and porcelain shards against the total number of shards is identical in Kota Cina and in Bukit Hasang, with some 25\% (cf. Table 6). This proportion is much lower for Si Pamutung, precisely $12 \%$, that is about half the figures observed in Kota Cina and in Bukit Hasang. It would be interesting to compare these figures with other more or less contemporary settlement sites, whether in Sumatra or in Java, to see if such difference is typical of coastal sites versus inland sites.

The situation is again undoubtedly in favour of Kota Cina as regards faunal remains not including shells (cf. Table 7). If the two series of excavations at Kota Cina are combined, the resulting density in weight per cubic metre reaches $712 \mathrm{~g}$, compared with just $25 \mathrm{~g}$ at Barus-Bukit Hasang, while the quantity is insignificant at Si Pamutung.

These statistics on three types of finds, put together as the Kota Cina project nears its completion as regards fieldwork, offer the opportunity to situate Kota Cina among the ancient settlement sites of North Sumatra, where extensive research has recently been conducted. Undoubtedly, Kota Cina appears to be the richest site, whether in earthenware, stoneware, porcelain, or in faunal remains.

\section{Research Prospects}

The rapid increase in modern constructions on the site, the stratigraphic complexity that becomes clearer with each season of archaeological excavation, as well as the results of the last two seasons encourage us to conduct further excavations.

The vicinity of the small Chinese temple, next to soil boring no. 70, between areas $\mathrm{E}$ and $\mathrm{C}$, constitutes a priority investigation area. As the subsoil survey conducted in 2014 revealed a high density of bricks to a depth of one metre over an area some 30 metres $x 30$ metres wide, it probably shelters a large shrine, if not the major temple of the Kota Cina ancient settlement.

The stimulating results obtained in 2015 in area $\mathrm{H}$, especially the discovery of remains of a complex wooden structure, of a boat framing member, as well as the uncovering of three midden layers in $\mathrm{KC} 44$, motivate to conduct further excavations in this area. This is all the more the case as soil borings carried

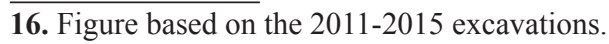

Archipel 91, Paris, 2016 
out in 2015 revealed the presence of artifacts and midden layers to the east and northeast of the 2015 excavations. Moreover, these excavations should also provide information on the northeastern boundary of the site.

The northern tip of the site yielded artifacts during a surface survey conducted in 2011. Therefore excavations are planned to the north of area A, where $\mathrm{KC} 3$ and $\mathrm{KC} 4$ were excavated in 2011.

Other excavations are planned to better define the eastern and southern boundaries of the settlement on still accessible land and out of the marshes bordering the site to the east. In the south, excavations conducted at KC27 and KC28 in 2014 yielded significant traces of ancient occupation. New excavations are therefore planned to the east and southeast of both squares.

Analyses of the finds constitute another major component of the project. The size of the stoneware and porcelain collection, amounting to some 44.000 shards today (weighting more than $530 \mathrm{~kg}$ ), approximates the size of the largest terrestrial archaeological collection published to date for a Sumatran site, namely that of Barus-Bukit Hasang (46.000 shards). By weight, it already represents more than twice the weight of the collection examined following the excavation of a single square at Kota Cina $\left(120 \mathrm{~m}^{2}\right.$ for a volume of about $120 \mathrm{~m}^{3}$, to the northwest of area D) in the 1970 s and published 40 years ago.

It is very likely that after the 2016 excavation season, stoneware and porcelain shards uncovered at Kota Cina since 2011 will constitute the largest collection of finds of this type from a terrestrial site in Sumatra, and probably Indonesia as a whole. It can therefore be stated that Kota Cina will represent a major reference site in Indonesia, and more widely in Southeast Asia, for finds of this type between the second half of the eleventh and the beginning of the fourteenth century.

In the context of the site, the study of imported stoneware and porcelain will represent a key aspect, by reminding us that this type of artifact constitutes the main dating material for Southeast Asian settlement sites dating from the ninth century CE onwards. For the last fifty years, the discovery of kiln sites in China, of shipwreck cargoes including large quantities of ceramics, as well as the systematic study of collections, allow us to refine the dating of certain types. It can be expected that the analysis of ceramics from various areas of the site combined with progress on dating made during the last 40 years, will produce a new dating bracket for the occupation of the site. Beyond the overall dating bracket, this analysis will also allow us to examine whether it is still possible to distinguish successive occupation layers in one or several areas. Eventually, as in the case of research conducted previously at Si Pamutung and at Barus Bukit-Hasang, the study of stoneware and porcelain will offer the opportunity to suggest a pattern of spatial evolution of the settlement. It will also increase the possibilities to compare the supplies reaching various sites, not only among North Sumatran sites, but also across the whole of maritime Southeast Asia. 
The current size of the earthenware collection (approx. 133.000 shards with a weight exceeding $1.230 \mathrm{~kg}$ ) is larger than the size of the collection uncovered at Barus Bukit-Hasang (approx. 121.000 shards with a weight of some $1.060 \mathrm{~kg}$ ). As regards quantity, the present Kota Cina collection is smaller than the collection uncovered at Si Pamutung in the Padang Lawas region (approx. 172.000 shards), but there shards are generally much smaller, since the weight of the latter collection is about $680 \mathrm{~kg}$. Also in weight, the present Kota Cina collection is already two and a half times larger than the Kota Cina collection examined in the 1970s following the excavation of a single square $\left(120 \mathrm{~m}^{2}\right.$ for a volume of about $120 \mathrm{~m}^{3}$, to the northwest of area D). It may be recalled that this pioneering study has never been published.

It is not over-optimistic to suggest that, by the end of the next season of excavation, work at Kota Cina since 2011 will have yielded finds which will make up the largest collection of earthenware from a terrestrial site in Sumatra ever studied. Once they, and the equally rich collection of stoneware and porcelain shards, have been studied, and hopefully the results published, Kota Cina will take its place as a major reference site in Indonesia, and more widely in Southeast Asia, for such finds for the period under consideration.

The wealth of the Kota Cina site in faunal remains has been amply confirmed through the 2014 and 2015 excavation seasons. The size and variety of this collection are probably unmatched regarding this period of time in Indonesia. Attention will be given to precise identification and distribution of these finds over the site.

Finally, it should be recalled that another important component of the project is underway. This is the paleo-environmental study for which a number of laboratory analyses are currently being conducted (cf. Chabot et al. 2013). 


\begin{tabular}{|c|c|c|c|c|c|}
\hline \multirow{2}{*}{$\begin{array}{c}\text { Area A } \\
42.5 \mathrm{~m}^{3}\end{array}$} & \multicolumn{2}{|c|}{ Earthenware } & \multicolumn{2}{c|}{ Stoneware \& porcel. } & Faun. remains \\
\cline { 2 - 6 } & qty & weight & qty & weight & weight \\
\hline raw fig. & 3,946 & 36,547 & 1,218 & 15,090 & 20,632 \\
\hline dens. $/ \mathrm{m}^{3}$ & 93 & 860 & 29 & 355 & 485 \\
\hline
\end{tabular}

\begin{tabular}{|c|c|c|c|c|c|}
\hline \multirow{2}{*}{$\begin{array}{c}\text { Area B } \\
18 \mathrm{~m}^{3}\end{array}$} & \multicolumn{2}{|c|}{ Earthenware } & \multicolumn{2}{c|}{ Stoneware \& porcel. } & Faun. remains \\
\cline { 2 - 6 } & qty & weight & Qty & weight & weight \\
\hline raw fig. & 1,960 & 19,255 & 1,168 & 16,096 & 2,458 \\
\hline dens. $/ \mathrm{m}^{3}$ & 109 & 1,070 & 65 & 894 & 137 \\
\hline
\end{tabular}

\begin{tabular}{|c|c|c|c|c|c|}
\hline \multirow{2}{*}{$\begin{array}{c}\text { Area C } \\
62.95 \mathrm{~m}^{3}\end{array}$} & \multicolumn{2}{|c|}{ Earthenware } & \multicolumn{2}{c|}{ Stoneware \& porcel. } & Faun. remains \\
\cline { 2 - 6 } & qty & weight & qty & weight & weight \\
\hline raw fig. & 28,815 & 216,429 & 8,179 & 74,589 & 13,344 \\
\hline dens. $/ \mathrm{m}^{3}$ & 458 & 3,438 & 130 & 1,185 & 212 \\
\hline
\end{tabular}

\begin{tabular}{|c|c|c|c|c|c|}
\hline \multirow{2}{*}{$\begin{array}{c}\text { Area D } \\
49.6 \mathrm{~m}^{3}\end{array}$} & \multicolumn{2}{|c|}{ Earthenware } & \multicolumn{2}{|c|}{ Stoneware \& porcel. } & Faun. remains \\
\cline { 2 - 6 } & qty & weight & qty & weight & weight \\
\hline raw fig. & 24,112 & 257,210 & 8,442 & 116,360 & 18,744 \\
\hline dens. $/ \mathrm{m}^{3}$ & 486 & 5,185 & 170 & 2,345 & 378 \\
\hline
\end{tabular}

\begin{tabular}{|c|c|c|c|c|c|}
\hline \multirow{2}{*}{$\begin{array}{c}\text { Area } \mathrm{E} \\
56.5 \mathrm{~m}^{3}\end{array}$} & \multicolumn{2}{|c|}{ Earthenware } & \multicolumn{2}{c|}{ Stoneware \& porcel. } & Faun. remains \\
\cline { 2 - 6 } & qty & weight & qty & weight & weight \\
\hline raw fig. & 49,149 & 485,888 & 15,117 & 170,665 & 29,849 \\
\hline dens. $/ \mathrm{m}^{3}$ & 869 & 8,599 & 267 & 3,020 & 528 \\
\hline
\end{tabular}

\begin{tabular}{|c|c|c|c|c|c|}
\hline \multirow{2}{*}{$\begin{array}{c}\text { Area F } \\
39.8 \mathrm{~m}^{3}\end{array}$} & \multicolumn{2}{|c|}{ Earthenware } & \multicolumn{2}{c|}{ Stoneware \& porcel. } & Faun. remains \\
\cline { 2 - 6 } & qty & weight & qty & weight & weight \\
\hline raw fig. & 12,977 & 88,251 & 4,048 & 32,560 & 12,884 \\
\hline dens. $/ \mathrm{m}^{3}$ & 326 & 2,217 & 101 & 818 & 323 \\
\hline
\end{tabular}

\begin{tabular}{|c|c|c|c|c|c|}
\hline \multirow{2}{*}{$\begin{array}{c}\text { Area G } \\
25.2 \mathrm{~m}^{3}\end{array}$} & \multicolumn{2}{|c|}{ Earthenware } & \multicolumn{2}{c|}{ Stoneware \& porcel. } & Faun. remains \\
\cline { 2 - 6 } & qty & weight & qty & weight & weight \\
\hline raw fig. & 4,506 & 35,007 & 1,105 & 12,073 & 430 \\
\hline dens. $/ \mathrm{m}^{3}$ & 178 & 1,389 & 43 & 479 & 17 \\
\hline
\end{tabular}

\begin{tabular}{|c|c|c|c|c|c|}
\hline \multirow{2}{*}{$\begin{array}{c}\text { Area } \mathrm{H} \\
48.3 \mathrm{~m}^{3}\end{array}$} & \multicolumn{2}{|c|}{ Earthenware } & \multicolumn{2}{|c|}{ Stoneware \& porcel. } & Faun. remains \\
\cline { 2 - 6 } & qty & weight & qty & weight & weight \\
\hline raw fig. & 7,071 & 77,303 & 3,475 & 65,369 & 24,546 \\
\hline dens. $/ \mathrm{m}^{3}$ & 146 & 1,600 & 71 & 1,353 & 508 \\
\hline
\end{tabular}

Table 1 - Comparison between excavated areas at Kota Cina (2011-15):

Earthenware, stoneware and porcelain, faunal remains (except shells). Weights in grams.

Volume indicates the estimated volume of excavated soil 


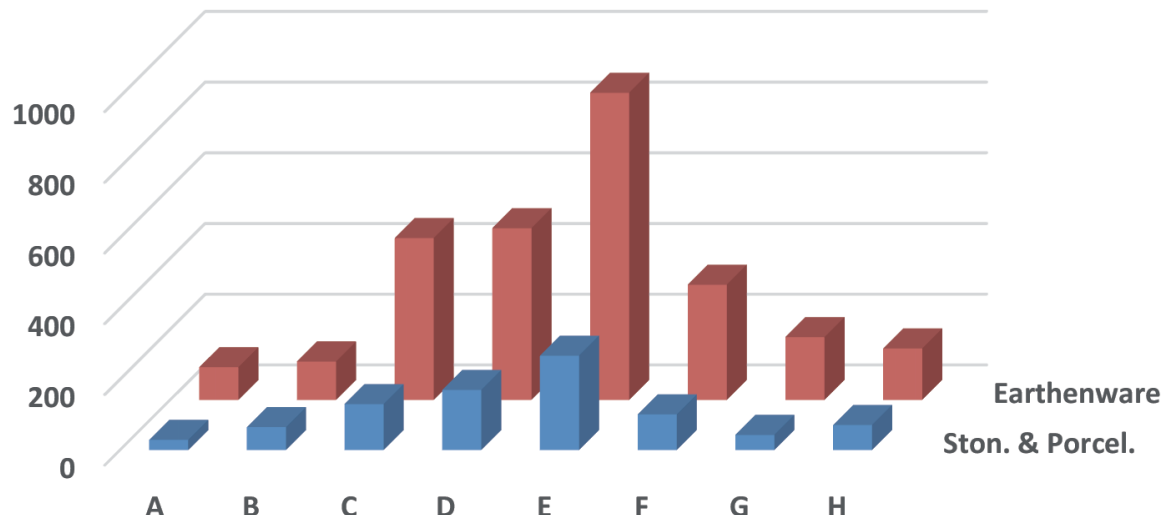

Chart 1 - Comparative density (per cubic metre per area) of earthenware, stoneware and porcelain (quantity of shards)

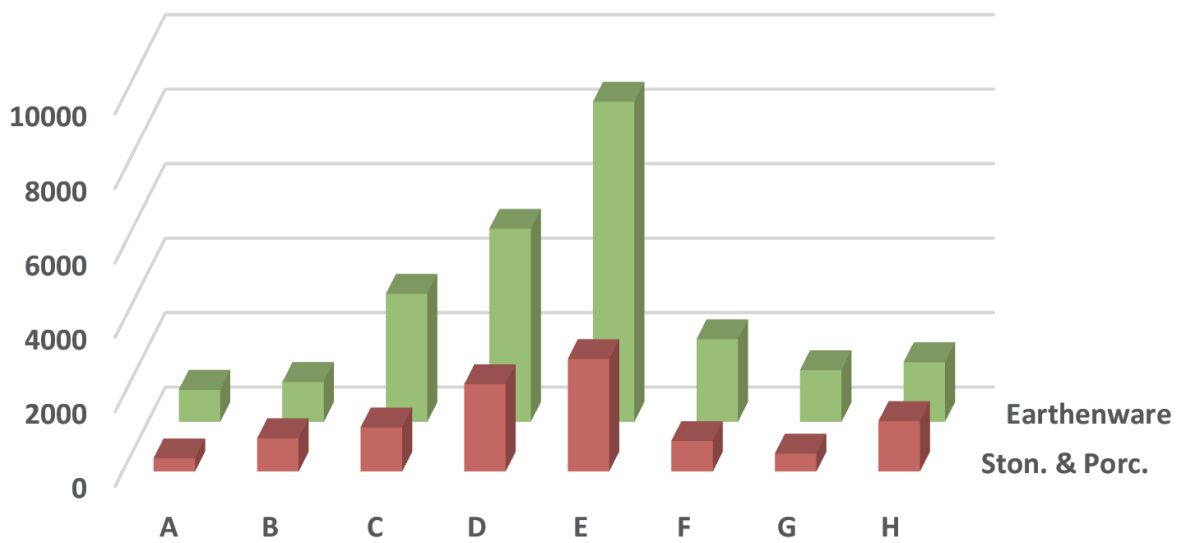

Chart 2 - Comparative density (per cubic metre per area) of earthenware, stoneware and porcelain (weight of shards) 


\begin{tabular}{|c|c|c|c|c|}
\hline Area & $\begin{array}{c}\text { Stoneware \& } \\
\text { porcel. }\end{array}$ & $\begin{array}{c}\text { Percent of total } \\
\text { density }\end{array}$ & Earthenware & $\begin{array}{c}\text { Percent of total } \\
\text { density }\end{array}$ \\
\hline A & 29 & 24 & 93 & 76 \\
\hline B & 65 & 37 & 109 & 63 \\
\hline C & 130 & 22 & 458 & 78 \\
\hline D & 170 & 26 & 869 & 74 \\
\hline E & 267 & 23 & 326 & 76 \\
\hline F & 101 & 24 & 178 & 81 \\
\hline G & 43 & 19 & 146 & 67 \\
\hline H & 71 & 33 & & 77 \\
\hline
\end{tabular}

Table 2 - Relative representativity (density per cubic metre per area) in stoneware/porcelain and earthenware (quantity of shards)

\begin{tabular}{|c|c|c|c|c|}
\hline Area & $\begin{array}{c}\text { stoneware \& } \\
\text { porcel. }\end{array}$ & $\begin{array}{c}\text { percent of total } \\
\text { density }\end{array}$ & earthenware & $\begin{array}{c}\text { percent of total } \\
\text { density }\end{array}$ \\
\hline A & 355 & 29 & 860 & 71 \\
\hline B & 894 & 46 & 1,070 & 54 \\
\hline C & 1,185 & 26 & 3,438 & 74 \\
\hline D & 2,345 & 31 & 5,185 & 69 \\
\hline E & 3,020 & 26 & 8,599 & 74 \\
\hline F & 818 & 27 & 2,217 & 73 \\
\hline G & 479 & 26 & 1,389 & 74 \\
\hline H & 1,353 & 46 & 1,600 & 54 \\
\hline
\end{tabular}

Table 3 - Relative representativity (density per cubic metre per area) in stoneware/porcelain and earthenware (weight of shards)

\begin{tabular}{|c|c|c|c|c|}
\hline & KC1975-77 & KC2011-15 & BKH2001-04 & PMTG2006-09 \\
\hline Surf. area $\left(\mathrm{m}^{2}\right)$ & 120 & 384 & 470 & 1,092 \\
\hline Vol. exc. $\left(\mathrm{m}^{3}\right)$ & 120 & 343 & 390 & 553 \\
\hline Shards nb. & - & 132,536 & 121,107 & 172,404 \\
\hline Weight $(\mathrm{g})$ & 477,073 & $1,215,890$ & $1,100,000$ & 687,190 \\
\hline Qty $/ \mathrm{m}^{2}$ & - & 345 & 257 & 157 \\
\hline Qty $/ \mathrm{m}^{3}$ & - & 386 & 310 & 311 \\
\hline Weight $/ \mathrm{m}^{2}(\mathrm{~g})$ & 3,975 & 3,166 & 2,340 & 629 \\
\hline Weight $/ \mathrm{m}^{3}(\mathrm{~g})$ & 3,975 & 3,544 & 2,820 & 1,242 \\
\hline
\end{tabular}

Abbreviations: KC, Kota Cina; BKH, Barus-Bukit Hasang; PMTG, Padang Lawas-Si Pamutung

Table 4 - Comparison of densities among three sites of North Sumatra (earthenware) 


\begin{tabular}{|c|c|c|c|c|}
\hline & KC1975-77 & KC2011-15 & BKH2001-04 & PMTG2006-09 \\
\hline \multirow{2}{*}{$\begin{array}{c}\text { Surf. area }\left(\mathrm{m}^{2}\right) \\
\text { Vol. exc. }\left(\mathrm{m}^{3}\right)\end{array}$} & 120 & 384 & 470 & 1,092 \\
\cline { 2 - 5 } & 120 & 343 & 390 & 553 \\
\cline { 2 - 5 } $\begin{array}{c}\text { Shards nb. } \\
\text { Weight }(\mathrm{g})\end{array}$ & - & 42,752 & 41,502 & 23,826 \\
\cline { 2 - 5 } & 260,664 & 502,802 & - & 140,501 \\
\cline { 2 - 5 } & - & 111 & 88 & 21 \\
\cline { 2 - 5 } $\begin{array}{c}\text { Qty } / \mathrm{m}^{2} \\
\text { Weight } / \mathrm{m}^{3}\end{array}$ & - & 125 & 106 & 43 \\
\cline { 2 - 5 } & 2,172 & 1,309 & - & 128 \\
\cline { 2 - 5 } & 2,172 & 1,466 & - & 254 \\
\hline
\end{tabular}

Abbreviations: KC, Kota Cina; BKH, Barus-Bukit Hasang; PMTG, Padang Lawas-Si Pamutung

Table 5 - Comparison of densities among three sites of North Sumatra (stoneware and porcelain)

\begin{tabular}{|c|c|c|c|c|}
\hline Site & $\begin{array}{c}\text { stoneware \& } \\
\text { porcel. }\end{array}$ & $\begin{array}{c}\text { percent of total } \\
\text { density }\end{array}$ & earthenware & $\begin{array}{c}\text { percent of total } \\
\text { density }\end{array}$ \\
\hline KC2011-15 & 125 & 24 & 386 & 76 \\
\hline BKH2001-04 & 106 & 25 & 310 & 75 \\
\hline PMTG2006-09 & 43 & 12 & 311 & 88 \\
\hline
\end{tabular}

Table 6 - Relative representativity (density per cubic metre per site) in stoneware/porcelain and earthenware (quantity of shards)

\begin{tabular}{|c|c|c|c|c|}
\hline & KC1975-77 & KC2011-15 & BKH2001-04 & PMTG2006-09 \\
\hline Surf. area $\left(\mathrm{m}^{2}\right)$ & 120 & 384 & 470 & 1,092 \\
\cline { 2 - 5 } $\begin{array}{c}\text { Vol. exc. }\left(\mathrm{m}^{3}\right) \\
\text { Weight }(\mathrm{g})\end{array}$ & 120 & 343 & 390 & 553 \\
\cline { 2 - 5 } & 207,000 & 122,887 & 9,825 & 189 \\
\cline { 2 - 5 } & 1,725 & 320 & 20 & $<1$ \\
Weight $/ \mathrm{m}^{2}(\mathrm{~g})$ & 1,725 & 358 & 25 & $<1$ \\
\hline
\end{tabular}

Table 7 - Comparison of densities among three sites of North Sumatra (faunal remains, except shells) 


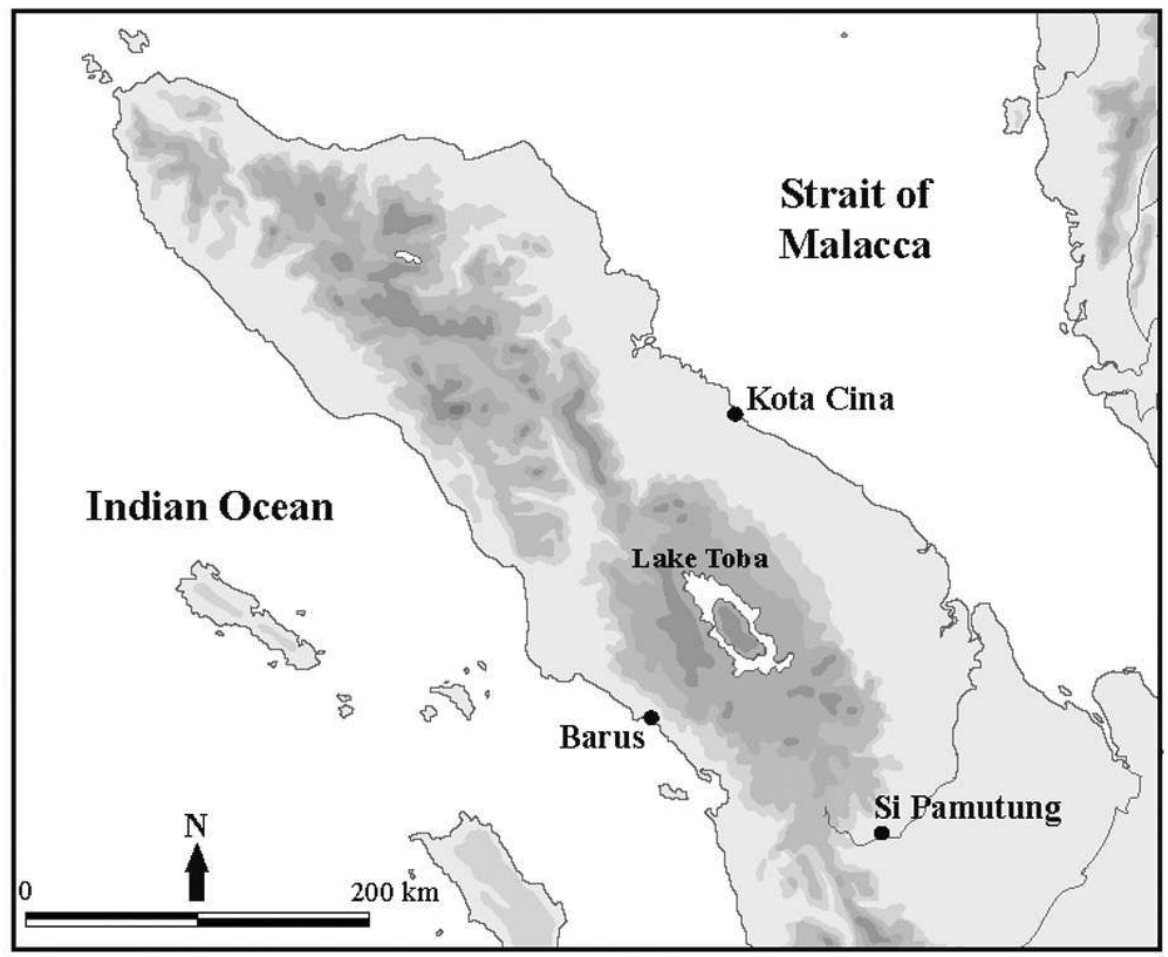

Fig. 1 - The main ancient settlement sites of North Sumatra (base map by Pierre Pichard).

Fig. 2 - The site of Kota Cina. Excavations and soil borings 2011-2015

(Kota Cina EFEO/PPAN Project, 2015) 


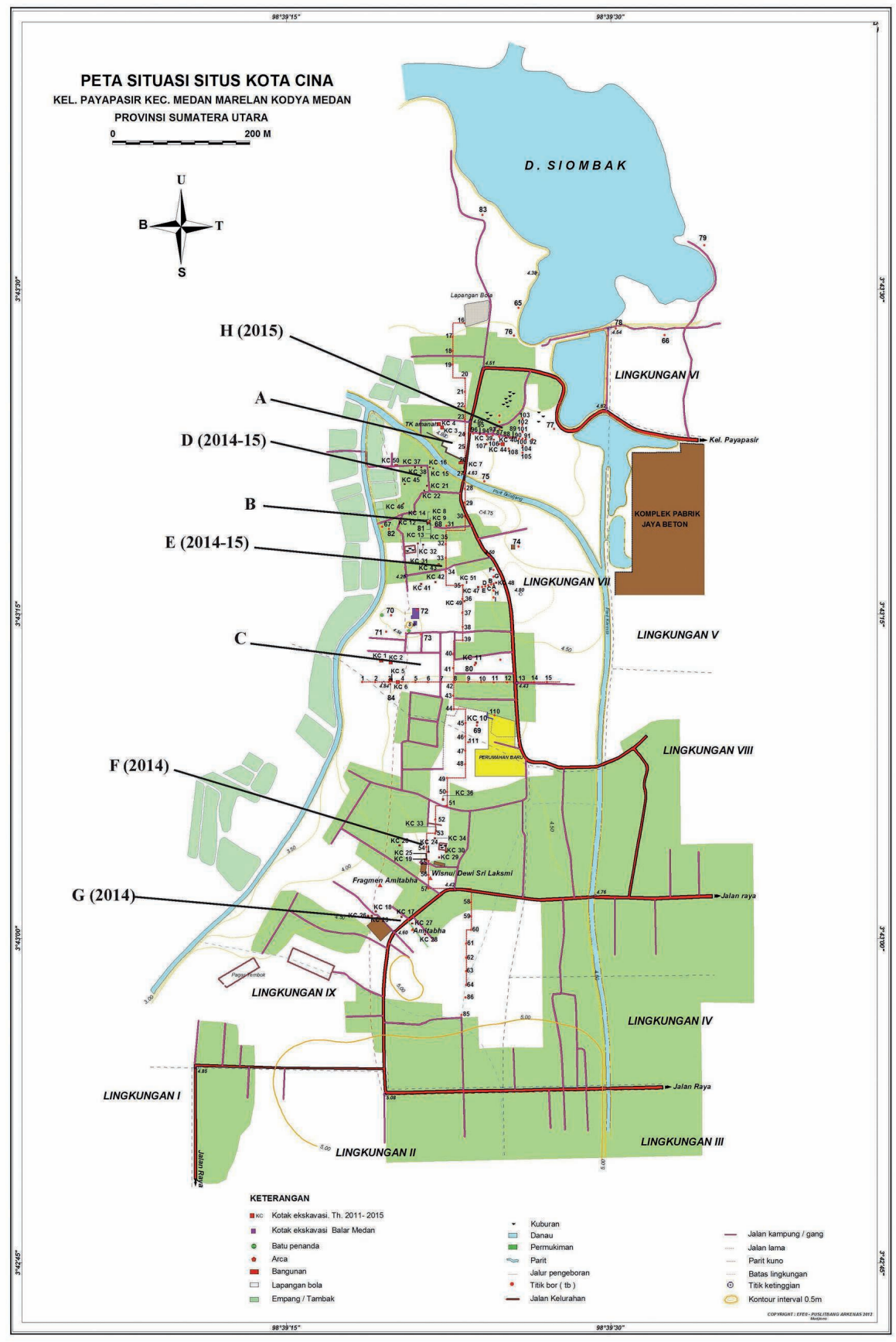




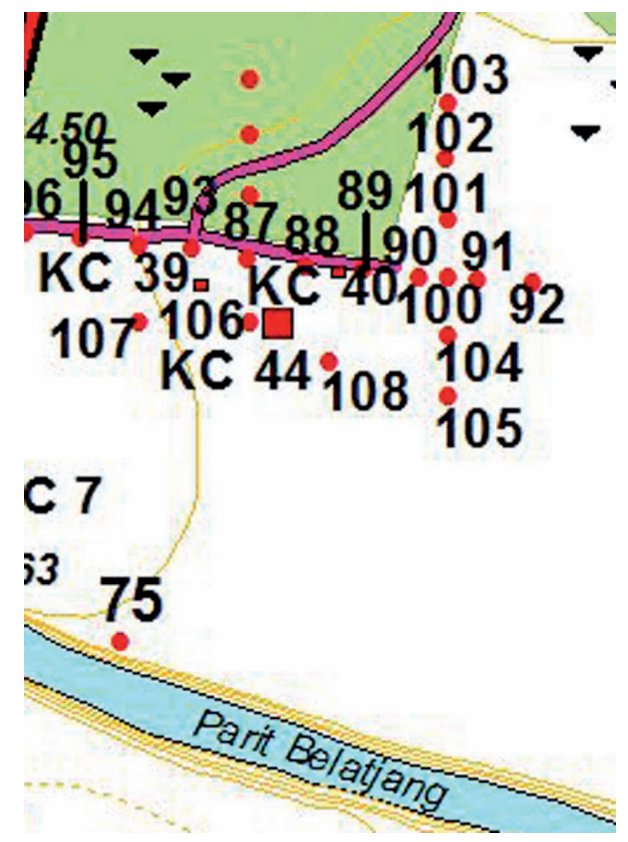

Fig. 3 - Map area H (excavations 2015 and soil borings) (Kota Cina EFEO/PPAN Project, 2015).

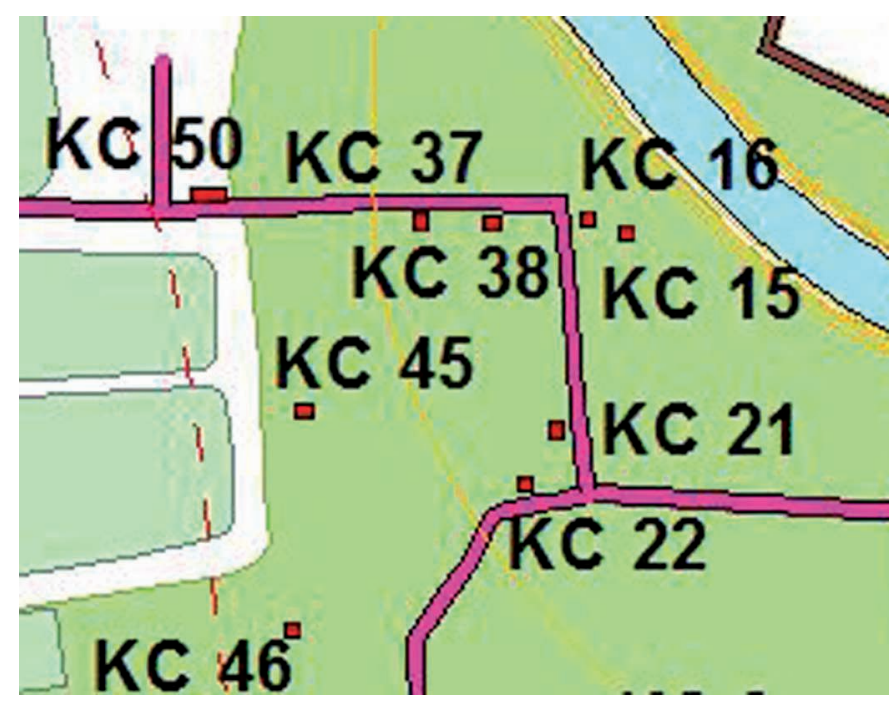

Fig. 4 - Map area D (excavations 2014-2015 and soil borings) (Kota Cina EFEO/PPAN Project, 2015). 


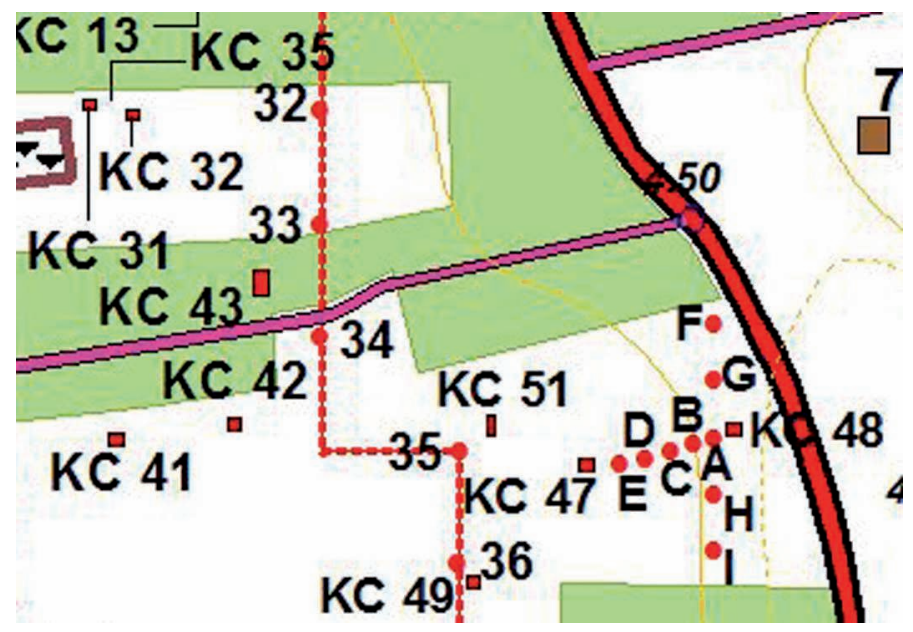

Fig. 5 - Map area E (excavations 2014-2015 and soil borings) (Kota Cina EFEO/PPAN Project, 2015).

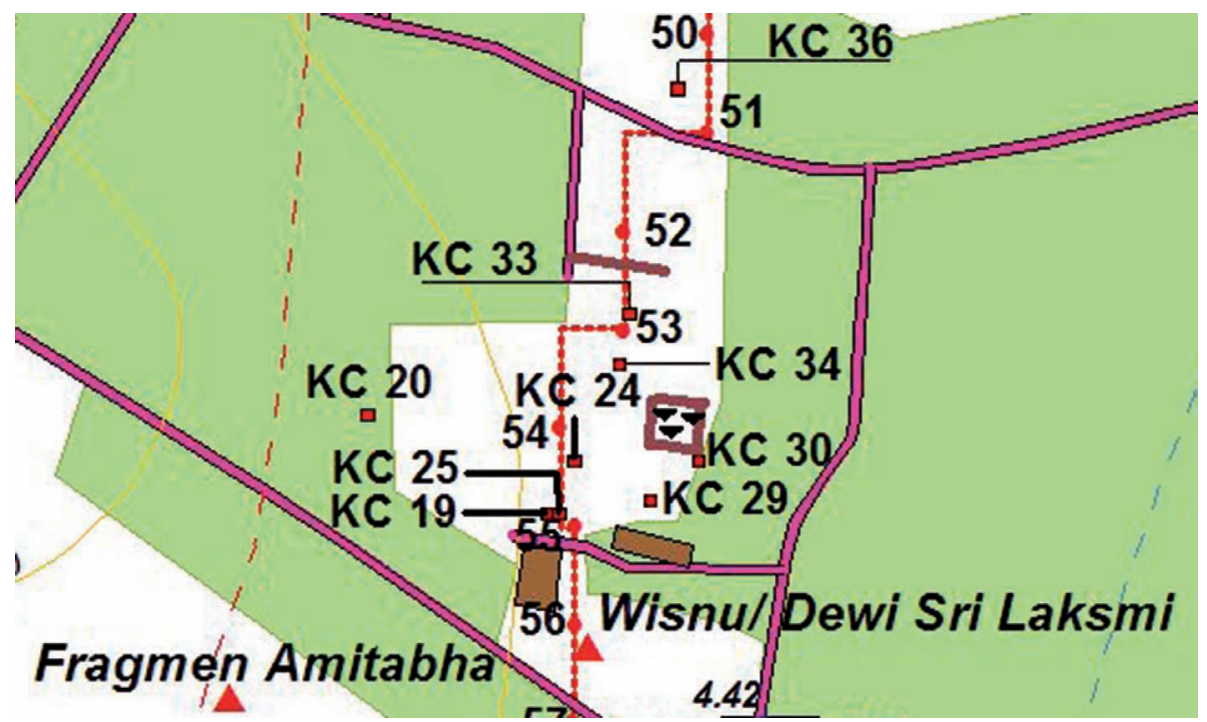

Fig. 6 - Map area F (excavations 2014 and soil borings) (Kota Cina EFEO/PPAN Project, 2015). 


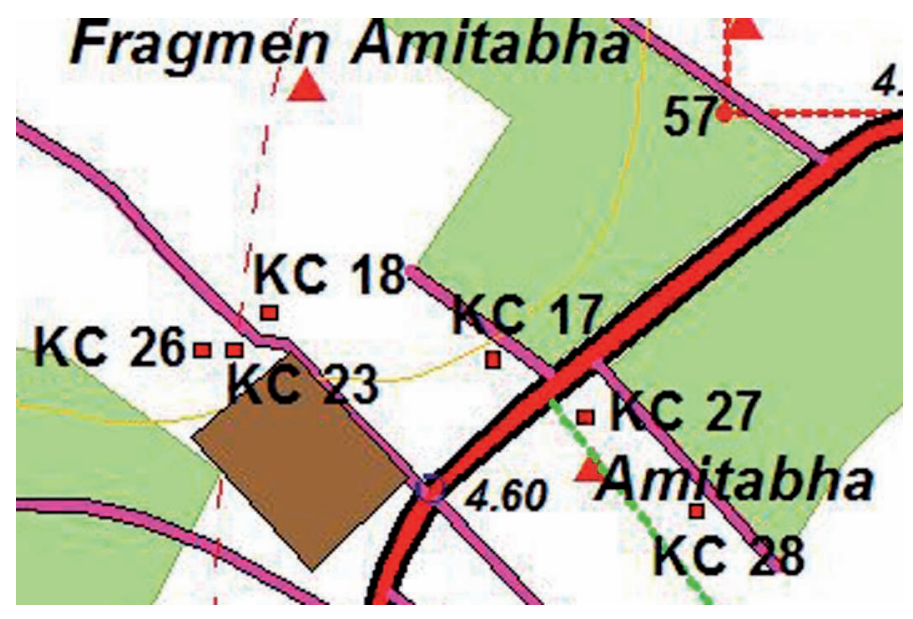

Fig. 7 - Map area G (excavations 2014 and soil borings) (Kota Cina EFEO/PPAN Project, 2015).

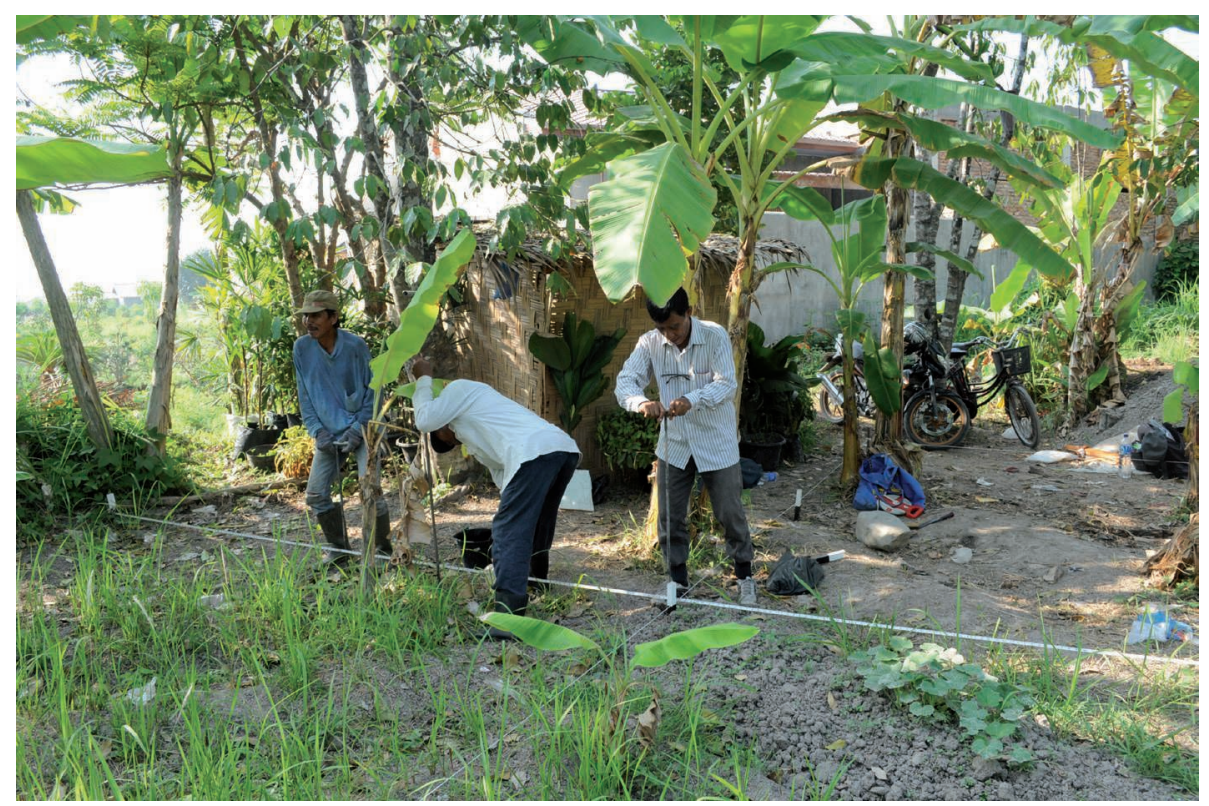

Fig. 8 - Subsoil survey in area G (phot. D. Perret, 2014). 


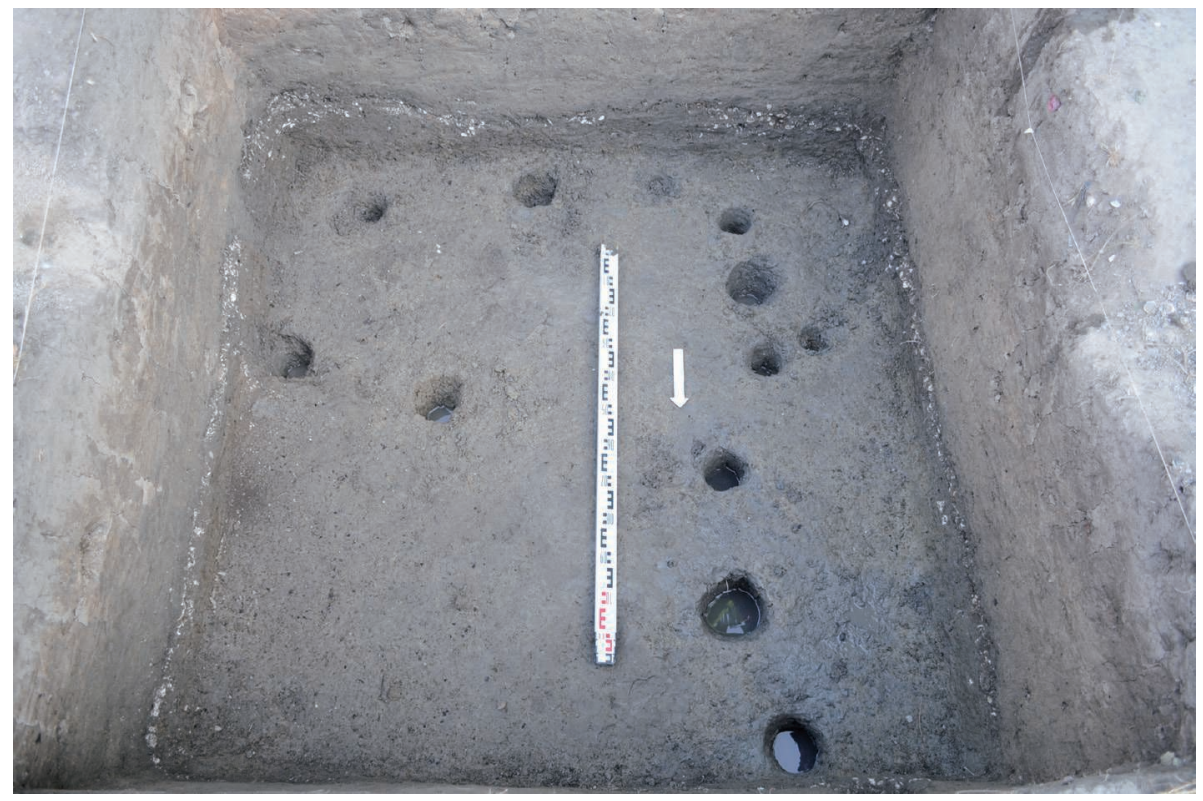

Fig. 9 - Midden layer and possible postholes in KC34 (phot. D. Perret, 2014).

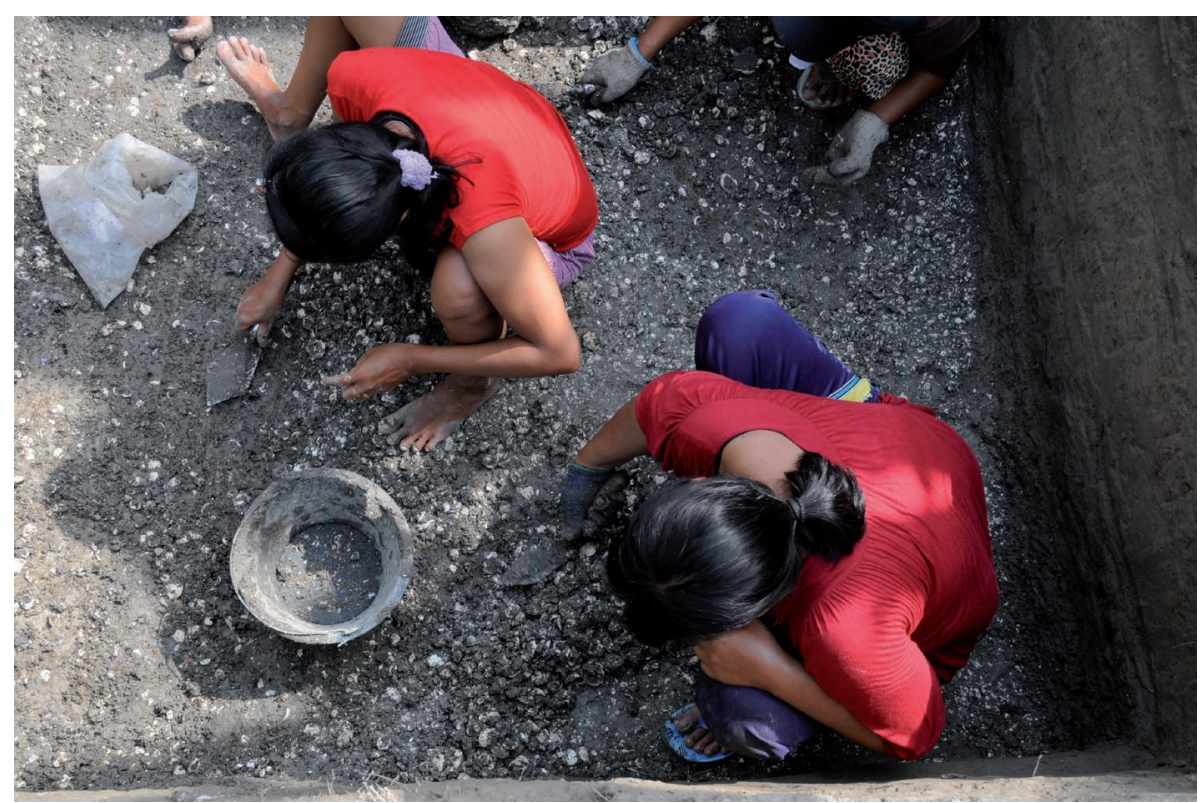

Fig. 10 - Uncovering of a midden layer in KC33, area F (phot. D. Perret, 2014). 


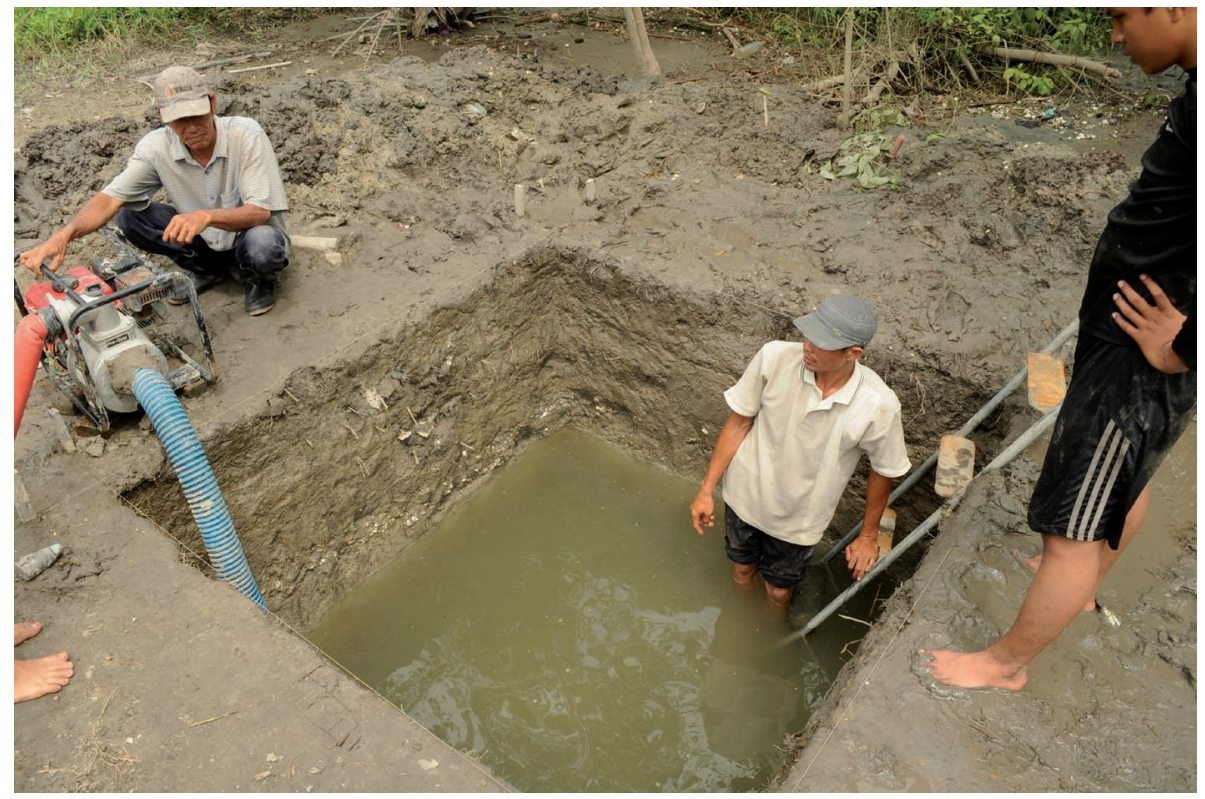

Fig. 11 - Underground water pumping in KC40 (phot. D. Perret, 2015).

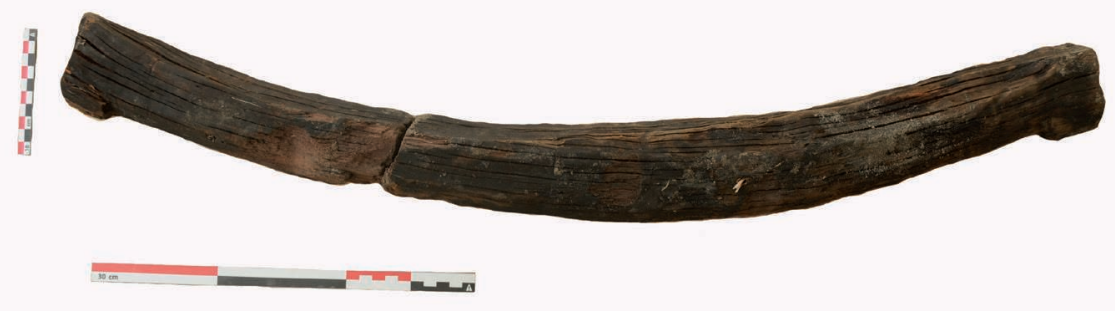

Fig. 12 - Boat framing member in KC44 (phot. D. Perret, 2015). 


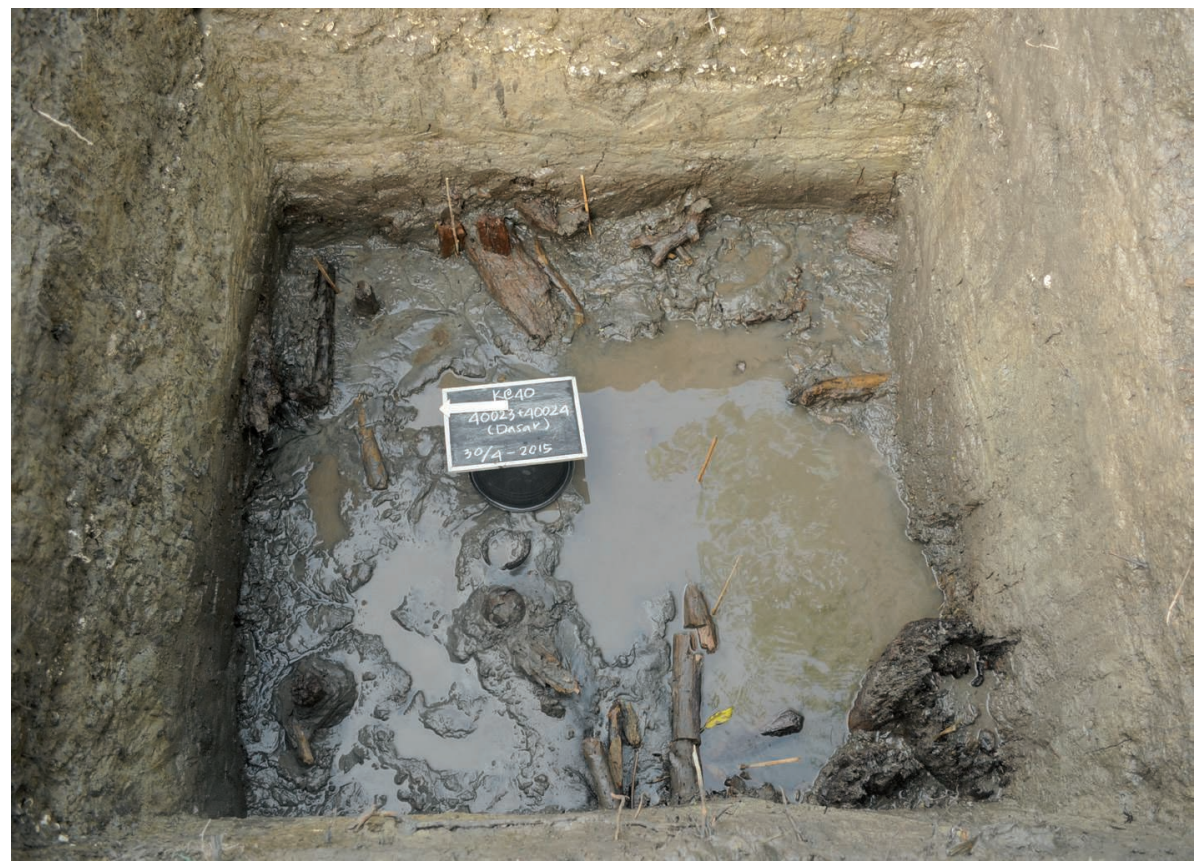

Fig. 13 - Remains of a wood structure in KC40 (phot. D. Perret, 2015).

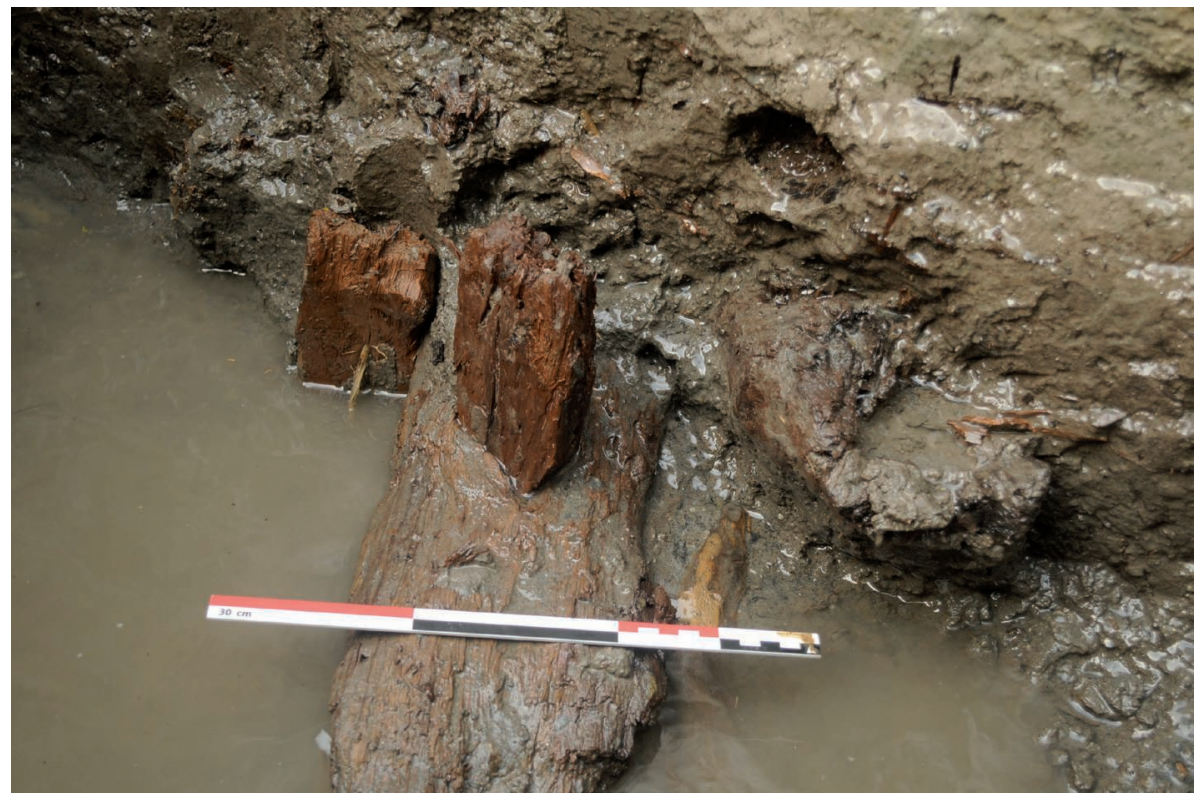

Fig. 14 - Example of joined pieces of wood in KC40 (phot. D. Perret, 2015). 


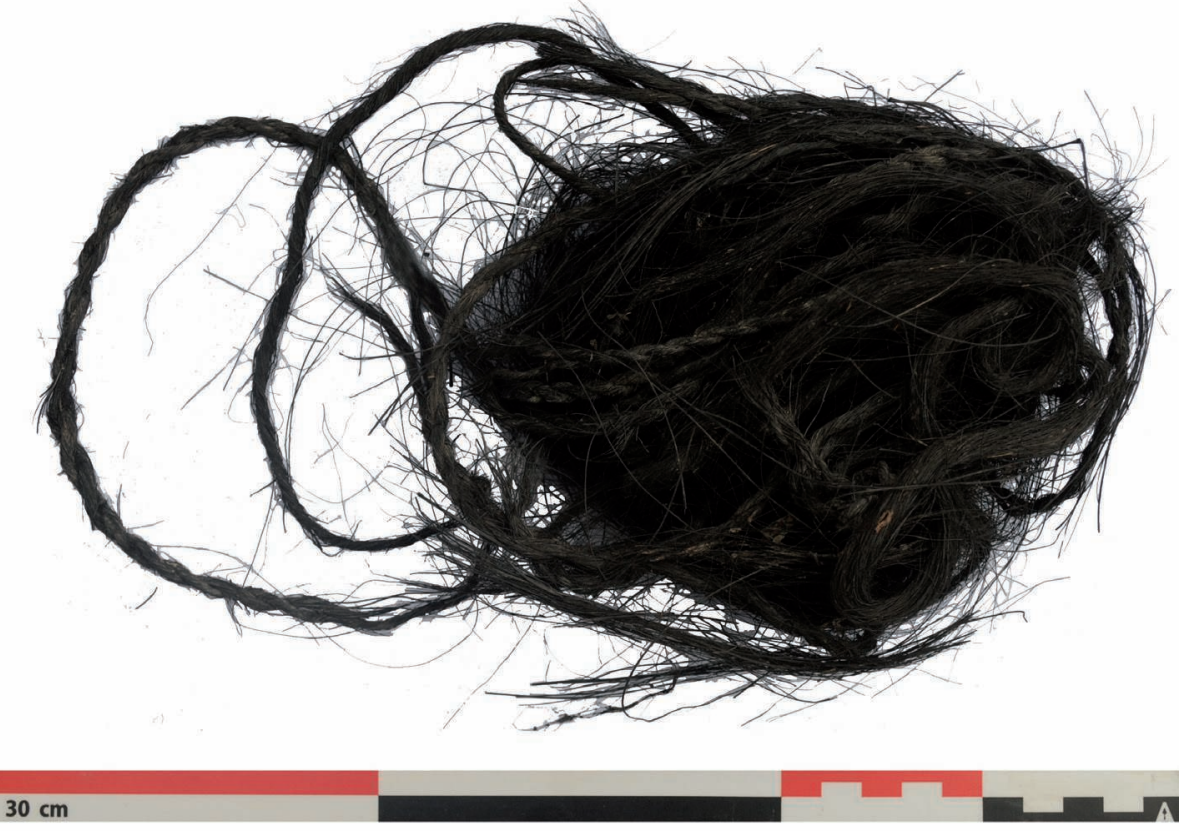

Fig. 15 - Fragments of ijuk cords from KC44 (phot. D. Perret, 2015). 